juhla ja joulu germaanis-skandinaavinen alkuperä? - Sananjalka 39 s. 55-64.

Kallio, Petri 2007: Kantasuomen konsonanttihistoriaa. - Jussi Ylikoski \& Ante Aikio (toim.), Sámit, sánit, sátnehámit. Riepmočála Pekka Sammallahtii miessemánu 21. beaivve 2007 s. 229-249. Suomalais-Ugrilaisen Seuran Toimituksia 253. Helsinki: Suomalais-Ugrilainen seura.

- 2014: The Diversification of ProtoFinnic. - Joonas Ahola, Frog \& Clive Tolley (toim.), Fibula, fabula, fact. The Viking age in Finland s. 155-168. Studia Fennica Historica 18. Helsinki: SKS.

SAARIKIVI, JANne 2015: REVIEW. - Nordic Journal of Linguistics 38 s. 100-107.

Samnordisk runtextdatabas. Uppsala universitet. https://www.nordiska.uu.se/forskn/ samnord.htm (11.1.2019).

SCHALIN, JohaN 2014: ScandinavianFinnish language contact in the Viking age in the light of borrowed names. - Joonas Ahola, Frog \& Clive Tolley (toim.), Fibula, fabula, fact. The Viking age in Finland, s. 399-436. Helsinki: SKS.

_ 2016: Östskandinavisk utveckling av den urnordiska $a i$-diftongen och palatalt $r$ i ljuset av finska ljudsubstitutioner. -
D. Andersson, L.-E. Edlund, S. Haugen, \& A. Westum (toim.), Studier i svensk språkhistoria 13. Historia och språkhistoria s. 241-262. Umeå: Institutionen för språkstudier, Umeå universitet \& Kungl. Skytteanska Samfundet.

2017a: Scandinavian front umlaut revisited and revised. - Arkiv för nordisk filologi 132 s. 5-74.

2017b: Scandinavian umlaut and contrastive feature hierarchies. - NorthWestern European Language Evolution (NOWELE) 70 s. 171-254.

Schalin, Johan \& Frog 2014: Toponymy and seafaring. Indications and implications of navigation along the Åland islands. - Joonas Ahola, Frog \& Jenni Lucenius (toim.), The Viking age in Åland. Insights into identity and remnants of culture s. 273-302. Helsinki: Finnish Academy of Science and Letters. SKS $=$ Suomalaisen Kirjallisuuden Seura.

SSA = Suomen sanojen alkuperä. Etymologinen sanakirja. $2 L-P$. Helsinki: Suomalaisen Kirjallisuuden Seura \& Kotimaisten kielten tutkimuskeskus 1995.

WIIK, KALEVI 1989: Ikivanha kuuntelutesti. Ääntäjinä kantagermaanit, kuuntelijoina kantasuomalaiset. Turku: Turun yliopisto.

\title{
Vuorovaikutuslingvistiikan jättiläinen
}

\section{Elizabeth Couper-Kuhlen \& Margret Selting: Interactional linguistics. Studying language in social interaction. Cambridge University Press 2018. 617 s. + verkkoliit- teet 291 s. ISBN 978-1-107-61603-5. Verkkoliit- teet ovat luettavissa osoitteessa http:// www.cambridge.org/interactional.}

Keskustelunanalyysin, antropologisen lingvistiikan sekä kieltä funktionaalisesta ja kontekstin huomioivasta näkökulmasta tarkastelevien kielitieteellisten suuntausten rajapinnassa syntynyt vuorovaikutuslingvistiikka (interactional linguistics) on parinkymmenen viime vuoden aikana kehittynyt omaksi tutkimussuuntauksekseen, jossa kieltä ja sen rakenteita tarkastellaan osana sosiaalista vuorovaikutusta. Alan tutkimusta tehdään eri puolilla maailmaa ja monien kielten parissa. Tätä 
tutkimusta on vuosien varrella koottu erilaisiin artikkelikokoelmiin. Osa kokoelmista on ollut yleisesityksiä (esim. Ochs, Schegloff \& Thompson toim. 1996; Selting \& Couper-Kuhlen toim. 2001), osa taas on ollut näkökulmaltaan rajatumpia ja keskittynyt esimerkiksi prosodiaan (CouperKuhlen \& Selting toim. 1996), syntaksiin ja sanastoon (Hakulinen \& Selting toim. 2005) tai lauserakenteiden ja sosiaalisten toimintojen yhdistämiseen (Laury, Etelämäki \& Couper-Kuhlen toim. 2017). Myös tieteellisissä lehdissä on julkaistu vuorovaikutuslingvististä tutkimusta esitteleviä erikoisnumeroita, jotka ovat käsitelleet muun muassa kieliopin ja episteemisyyden yhteyttä (Lindström, Maschler \& Pekarek Doehler toim. 2016) sekä kielen ja vuorovaikutuksen yksiköitä (Helasvuo, Kärkkäinen \& Endo toim. 2018).

Elizabeth Couper-Kuhlenin ja Margret Seltingin teos Interactional linguistics: Studying language in social interaction tuo merkittävän panoksen vuorovaikutuslingvistiikan kenttään kokoamalla eri kielistä saatuja tutkimustuloksia yksien kansien väliin. Samalla teos on ensimmäinen vuorovaikutuslingvistiikalle omistettu oppikirja, joka paitsi havainnollistaa, kuinka vuorovaikutusta ja keskustelupuhetta voidaan analysoida kielitieteellisestä näkökulmasta, myös tarjoaa yleiskatsauksen tutkimusalan teoreettisesta taustasta, metodologiasta ja tämänhetkisestä tilasta.

Perusteellinen, yli 60o-sivuinen teos koostuu yhdeksästä luvusta. Painettua teosta täydentävät verkossa avoimesti julkaistut kuusi lukua, jotka on nivottu huolellisesti osaksi teoksen kokonaisuutta ja sisällysluetteloa. Verkkoliitteineen teos on yli 900 sivun mittainen järkäle.

Johdannon ja loppupäätelmien väliset luvut on teoksessa jaettu kahteen osioon. Niistä ensimmäisessä ("How is interaction conducted with linguistic resources?") otetaan lähtökohdaksi sosiaalinen vuorovaikutus ja esitellään, kuinka sitä jäsennetään ja säädellään kielellisten resurssien avulla. Toisessa osiossa ("How are linguistic resources deployed in interaction?") lähdetään liikkeelle vastakkaisesta suunnasta - kielellisistä resursseista - ja tarkastellaan, miten erilaisia resursseja käytetään ja hyödynnetään vuorovaikutuksellisessa toiminnassa. Kirjan loppuun on sijoitettu liitteiksi sekä perinteisen keskustelunanalyyttisen että saksalaisella kielialueella vakiintuneen GAT-systeemin (Gesprächsanalytisches Transkriptionssystem) mukaiset litterointimerkit selityksineen.

Kirja on rakenteeltaan selkeä ja johdonmukainen. Oppikirjamaisuus näkyy hyvällä tavalla teoksen rakenteessa: jokainen luku on jaettu keskeisten käsitteiden mukaan nimettyihin alalukuihin, joiden lopussa - ja tarpeen mukaan keskelläkin - on jakson keskeiset seikat tiivistävä yhteenvetolaatikko. Aiheita esitellään ja havainnollistetaan eri kielistä poimittujen keskusteluesimerkkien avulla. Niissä edustuvien kielten kirjo on laaja: mukana on kieliä Euroopasta (mm. englanti, saksa, suomi, tanska, venäjä ja viro), mutta myös muualta maailmasta ( $\mathrm{mm}$. japani, korea, lao, mandariinikiina ja Papua-Uudessa-Guineassa puhuttu yeli dnye). Eri kielten vuorovaikutuskäytänteitä ja niiden toteuttamistapoja vertailemalla teoksessa nostetaan ilahduttavasti esille myös typologinen näkökulma ja kiinnitetään huomiota siihen, kuinka erot kielten (ja kulttuurien) välillä voivat johtaa eroihin myös vuorovaikutuksen käytänteissä.

Fennistejä kiinnostaa varmasti suomenkielisten esimerkkien ja tutkimuksen vahva esilläolo teoksessa. Tämä ei sinänsä ole ihme, sillä Suomessa on viime vuosina tehty paljon vuorovaikutuslingvististä tutkimusta - paitsi Helsingin yliopiston Intersubjektiivisuus vuorovaikutuksessa -huippuyksikössä myös esimerkiksi Oulun ja Turun yliopistoissa. Toinen teoksen tekijöistä, Elizabeth Couper-Kuhlen, on työskennellyt Helsingin yliopistossa 
FiDiPro-professorina (2009-2013) ja ollut mukana edellä mainitussa huippuyksikössä.

\section{Vuorovaikutuslingvistiikka teoriana ja metodina}

Kirjan aloittaa 26-sivuinen johdanto, jossa käsitellään vuorovaikutuslingvistiikan historiaa, kehitystä ja menetelmiä sekä niiden mukanaan tuomia teoreettisia implikaatioita. Osio on kirjoitettu selkeästi, ja se avaa vuorovaikutuslingvististä lähestymistapaa myös aiheeseen aiemmin perehtymättömälle. Tekijät käyvät ensin kattavasti läpi alan kehityksen kannalta keskeiset lähtökohdat ja taustateoriat (keskustelunanalyysi, gumperzilainen kontekstualisaatioteoria ja lingvistinen antropologia). Tämän jälkeen he esittelevät, kuinka vuorovaikutuslingvististä analyysia tehdään ja millaisia aineistoja käytetään. Samoja seikkoja on esitelty jo aiempien kokoomateosten johdannoissa (ks. Schegloff, Ochs \& Thompson 1996; Couper-Kuhlen \& Selting 2001) mutta ei yhtä systemaattisesti. Teoksen johdantoa täydentää verkkoliitteen luku, jossa esitellään vuorovaikutuslingvistisen tutkimuksen etuja: yhtäältä sitä, mitä kielentutkimus voi antaa vuorovaikutuksen tutkimukselle, toisaalta sitä, miksi kieltä kannattaa tutkia nimenomaan puhutun vuorovaikutuksen aineistoista.

Keskustelunanalyyttisen tutkimuksen vaikutus vuorovaikutuslingvistiikkaan on huomattava, mitä johdannossa tähdennetään useaan otteeseen (ks. erit. s. 17-18). Alojen välisen suhteen jäsentäminen heti johdantoluvussa on onnistunut ratkaisu, sillä se selventää lukijalle, mikä vuorovaikutuslingvistiikassa on uutta ja erilaista suhteessa keskustelunanalyysiin. Yksi keskeisimmistä eroista liittyy alojen tutkimuksellisiin päämääriin: keskustelunanalyysissa ollaan ensisijaisesti kiinnostuneita vuorovaikutuksen sekventiaalisesta ja sosiaalisesta järjestäytymisestä, vuorovai- kutuslingvistiikassa puolestaan halutaan selvittää, kuinka kieltä ja sen rakenteita käytetään vuorovaikutuksessa. Vuorovaikutuslingvistisen tutkimuksen toivotaan ajan myötä myös vaikuttavan kielitieteen eri alojen käsitykseen kielen luonteesta. Couper-Kuhlen ja Selting huomauttavat kuitenkin aiheellisesti, että erilaisista tavoitteista huolimatta keskustelunanalyysia ja vuorovaikutuslingvistiikkaa ei ole aina mahdollista erottaa toisistaan. Tämä käy ilmi myös teoksessa myöhemmin esiteltävistä tutkimuksista, joista monet sijoittuvat vuorovaikutuslingvistiikan ja keskustelunanalyysin yhteisalueelle.

Johdannossa painotetaan vuorovaikutuslingvistiikan empiiristä, aineistovetoista lähestymistapaa kielen tutkimiseen (ks. erit. s. 18-19). Tekijät korostavat läpi teoksen sitä, että vuorovaikutuslingvistiikassa kaikki teoreettiset käsitteet ja niiden olemassaolon oikeutus perustuvat nimenomaan luonnollisista vuorovaikutusaineistoista nousseisiin havaintoihin. Tämän takia onkin hieman harmillista, että johdannossa ei juuri käsitellä sitä, kuinka ja missä määrin vuorovaikutuslingvististä lähestymistapaa voitaisiin soveltaa erityyppisten aineistojen käsittelyyn. Aineistojen hankintaa ja käyttöä koskevat luonnehdinnat jäävät yleisiksi: tekijöiden mukaan aineistot ovat tyypillisesti peräisin arkisista tai institutionaalisista vuorovaikutustilanteista - kasvokkaisista tai puhelinvälitteisistä - kahden tai useamman osanottajan välillä (s. 19). Näkemykset tuntuvat nykyisen viestintäkulttuurin näkökulmasta hieman suppeilta: entä verkossa tai muissa teknologisissa ympäristöissä käytävät keskustelut? Kysymystä käsitellään teoksessa kappaleen verran (s. 20); kirjoittajat toteavat, että teknologiavälitteisen vuorovaikutuksen käyttäminen aineistona on mahdollista mutta haastavaa. Myös teoksessa näytetyt esimerkit ovat peräisin niin sanotuista perinteisistä, kasvokkaisista tai puhelimen välityksellä tapahtuvista keskustelu- 
aineistoista. On totta, että teknologiavälitteisistä keskusteluista ei ole vielä laajalti olemassa vuorovaikutuslingvististä tutkimusta (ks. kuitenkin esim. Helasvuo 2014) ja että vuorovaikutuslingvistiikan soveltaminen tällaisiin aineistoihin ei ole aina mutkatonta. Ehkäpä kuitenkin hieman kattavampi pohdinta aineistojen monimuotoisuudesta ja vuorovaikutuslingvistiikan sovellusmahdollisuuksista olisi ollut paikallaan. Ylipäänsä lukija jää johdannon luettuaan kaipaamaan määritelmää sille, mitä sosiaalisella vuorovaikutuksella vuorovaikutuslingvistiikassa tarkoitetaan ja miten se suhteutuu esimerkiksi keskustelun tai kommunikaation käsitteisiin. Kuva kuitenkin selkeytyy esimerkkien analyysien myötä.

\section{Kielellisten resurssien rooli vuorovaikutuksen jäsentymisessä}

Teoksen johdantoa seuraavassa osiossa I käsitellään kielellisten resurssien roolia vuorovaikutuksen säätelyssä. Osion aloittaa lyhyt johdanto, jossa esitellään osion keskeiset käsitteet: toiminto, sekvenssi, toiminta, käytänne ja resurssi. Näistä käytänne nähdään erityisen olennaisena terminä; käytänteet ovat yhdysside kielellisten resurssien (muotojen ja rakennemuottien) ja sosiaalisten toimintojen välillä. Vuorovaikutuskäytänne muodostuu, kun tietyn toiminnon aikaansaamiseksi käytetään toistuvasti tiettyjä kielellisiä keinoja (s. 28).

Osion toisessa luvussa käsitellään vuoron rakentumista ja vuorottelua. Kirjoittajat havainnollistavat systemaattisesti, kuinka vuoron rakenneyksiköiden ja vuorojen rakentumiseen sekä vuorotteluun vaikuttavat paitsi vuorovaikutuksen kontekstuaaliset tekijät myös kullekin kielelle ominainen rakenne ja kielen syntaktiset ja prosodiset piirteet. Luvussa 3 esitellään kattavasti ja yksityiskohtaisesti korjauskäytänteitä ja kootaan yhteen aiempaa aiheesta tehtyä tutkimusta.
Kielellisten käytänteiden muodostumisen kannalta erityisen mielenkiintoinen on luku 4, jossa keskitytään toimintojen muotoiluun ja tunnistamiseen ( $a c$ tion formation and ascription). Luvussa käsiteltyjä toimintoja ja niihin liittyviä käytänteitä - responssit mukaan lukien ovat 1) kysymykset (questions), 2) tarjoukset (offers) ja pyynnöt (requests), 3) uutisoinnit (news deliveries) ja informoinnit (informings) sekä 4) kannanotot (assessments), kehut (compliments) ja itsen vähättelyt (self-deprecations). Kyseiset toiminnot edustavat teoksessa neljää erityyppistä aloittavien toimintojen luokkaa.

Luvun 5 aiheena on topikaalisuus ja sekventiaalisuus, jotka edustavat kahta erilaista lähestymistapaa siihen, kuinka keskustelu järjestyy yhtenäiseksi ja säännönmukaiseksi kokonaisuudeksi. Topikaalisuus liittyy puheen järjestäytymiseen sisällön mukaan, sekventiaalisuus taas kuvaa puheen rakenteellista järjestäytymistä toimintajaksoiksi. Painettuja lukuja täydentävät verkkoluvut preferenssistä, asenteen (stance) osoittamisesta ja asennonvaihdoksista (footing) sekä tarinankerronnasta (storytelling).

Kaiken kaikkiaan ensimmäisessä osiossa esitellään kattavasti aineistoesimerkkien ja aiempien tutkimusten valossa sitä, kuinka (arki)keskustelut rakentuvat ja millaisia kielellisiä resursseja keskustelun rakentumisessa ja sen eri toiminnoissa hyödynnetään. Osiosta nousee kiintoisalla tavalla esiin se, että kullekin kielelle ominainen rakenne vaikuttaa paitsi vuorojen vaihtumiseen ja näin vuorovaikutuksen etenemiseen myös siihen, kuinka erilaisia sosiaalisia toimintoja voidaan saada aikaan. Kielen rakenteen vaikutus vuorotteluun nousee erityisesti esiin projektion eli vuoronvaihtojen ennakoitavuuden osalta: joidenkin kielten (esim. englanti ja saksa) rakenne mahdollistaa aikaisen projektion (early projection) ja vuoronvaihdon, kun taas toisissa kielissä (esim. japani) lausuman merkitys ja mah- 
dollinen lopetuskohta täsmentyvät varsin myöhään (delayed projection) (ks. myös Tanaka 1999). Osio onkin erinomaista luettavaa myös keskustelunanalyytikolle, joka kaipaa työkaluja vuorovaikutuksen mikrotason analyysiin.

\section{Kielelliset resurssit vuorovaikutuksen välineinä}

Teoksen toisessa osiossa kirjoittajat vaihtavat näkökulmaa ja siirtyvät tarkastelemaan, kuinka erityyppisiä kielellisiä resursseja hyödynnetään vuorovaikutuksessa. Osio alkaa edellisen tavoin johdannolla, jossa esitellään jakson pääkäsite kielellinen resurssi. Tekijät tarkoittavat sillä tiettyyn muotoon perustuvaa kokonaisuutta, jollaisiksi katsotaan teoksessa sekä sanalliset (verbal) että ei-sanalliset (non-verbal) yksiköt. Edellistä edustavat muun muassa foonit ja muut äännähdykset, morfit, sanat, lausekkeet, lauseet ja lausetta laajemmat yksiköt. Jälkimmäiseen luokkaan kuuluvat esimerkiksi prosodia, ilmeet, eleet, kehon asento ja liike siinä määrin kuin ne systemaattisesti ovat sidoksissa kielen avulla tapahtuvaan kommunikointiin.

Osion johdantoa seuraa luku 6, jossa selvitetään, millaisia yksiköitä virkkeet (sentence) $)^{1}$, lauseet (clauses) ja lausekkeet (phrases) ovat vuorovaikutuksessa ja miten ne muodostuvat siinä. Tämän jälkeen käsitellään lauseyhdistelmien tehtäviä vuorovaikutuksessa (luku 7). Luvussa 8 tarkastellaan partikkeleita, joita kirjoittajat kutsuvat "itsenäisiksi yhden sanan konstruktioiksi” sen vuoksi, että niitä ei taivuteta eivätkä ne kuulu syntaktisiin rakenteisiin, mutta niillä voidaan kuitenkin toteuttaa erilaisia sosiaalisia toimintoja. Teoksen toisen osan täydennyksinä ovat

1. Teoksessa termillä sentence tarkoitetaan sekä yksinäislauseesta että lauseyhdistelmistä muodostuvia yksiköitä. Termin käytön taustalla on saksalaisen tutkimusperinteen käsite Satz. verkkoluvut vuorovaikutuksen prosodisista ja foneettisista ulottuvuuksista sekä erityyppisistä ja omanlaisiaan käytänteitä muodostavista kielellisistä ilmiöistä (esim. puhuttelusta, toistosta, listaamisesta ja erityyppisistä esitoiminnoista).

Myös kielellisten resurssien käsittelyssä kirjoittajat korostavat kieltenvälisen ja vertailevan tutkimuksen tärkeyttä, vaikkakin vertailun tekee haastavaksi se, että yhden kielen kuvausta varten kehitetyt kategoriat eivät välttämättä ongelmitta kuvaa jotakin toista kieltä, puhumattakaan kaikista maailman kielistä. Jotta kieltenvälinen vertailu on mahdollista, on tarkasteltavien kielten kieliopillisten kategorioiden oltava riittävän samanlaisia. Couper-Kuhlen ja Selting toteavat lisäksi, että vertailtavien kielten kielioppien läpikotainen tunteminen on välttämätöntä uskottavan vertailevan analyysin toteuttamiseksi. Tämän vuoksi valtaosa heidän esittämistään esimerkeistä onkin peräisin englannin- ja saksankielisistä keskusteluista.

Toisen osion merkittävin ansio on mielestäni se, että siinä osoitetaan järjestelmällisesti, miten kielelliset muodot ja rakenteet ovat rajoiltaan joustavia, tilanteeseen mukautuvia ja monesti yhteistoiminnallisesti tuotettuja. Osiossa käsitellään kiinnostavasti myös sellaisia tapauksia, joissa puhutun vuorovaikutuksen kielioppi ei noudata normatiivisten kielioppien sääntöjä ja odotuksia. Osiossa esitetyt kuvaukset esimerkiksi lauseesta tai nominaalilausekkeesta puhutun vuorovaikutuksen yksikköinä nostavat esiin sen, kuinka monet kielitieteeseen vakiintuneet käsitykset ovat tutkimuksessa käytettyjen kirjoitettua yleiskieltä edustavien aineistojen vinouttamia (ks. myös Linell 2005). Fennistiikassa kielioppikuvaukset ovat toki jo pitkään perustuneet autenttisiin aineistoihin sekä puhutun että kirjoitetun kielen osalta mistä hyvänä esimerkkinä toimii Iso suomen kielioppi (ISK) - ja harva fennisti 
varmaankaan ajattelee nykypäivänä yleiskieltä jonkinlaisena ensisijaisena kielimuotona. Kaikkialla maailmassa kielioppikuvaus ei kuitenkaan ole yhtä käyttöpohjaista. Esimerkiksi luvussa 8 käsiteltävät partikkelit ovat ryhmä yksiköitä, joka on usein perinteisissä kielioppikuvauksissa sivuutettu "täytesanoina". Esittelemällä partikkeleista tehtyjä vuorovaikutuslingvistisiä tutkimuksia CouperKuhlen ja Selting kuitenkin havainnollistavat, millaisia merkittäviä ja hienovaraisia paikallisia tehtäviä partikkeleilla on itsenäisesti ja osana erityyppisiä vuorovaikutuksellisia toimintoja. Suomalaisia kielentutkijoita saattaa kiinnostaa, että juuri suomi nostetaan esiin partikkeleiltaan rikkaana kielenä (s. 503-505).

\section{Vuorovaikutuslingvistisen tutkimuk- sen rooli kielentutkimuksessa}

Kirja päättyy yhteenvetoon (luku 9), jossa pohditaan, mikä merkitys kirjassa esitetyillä tutkimustuloksilla on yleiskielitieteellisesti ja mitä annettavaa vuorovaikutuslingvistiikalla on kielentutkimuksen teorioille. Yhteenvedossa kirjoittajat tiivistävät teoksensa pääsanoman ja vakuuttavat näin lukijan siitä, että kieltä tulee tutkia sen käyttökonteksteissa, osana sosiaalista kanssakäymistä. Kielentutkijan on tärkeää ottaa huomioon myös kielen dynaamisuus, yhteisöllisyys ja toiminnallisuus sekä sen ajassa lineaarisesti kehittyvä, emergentti luonne, joka sallii kielen rakenteiden projektion, paikalliset laajennukset sekä edellä sanotun muokkaamisen korjauskäytänteiden avulla. Vuorovaikutuslingvistiikka näkee kielen todellistuvan käytössä, minkä vuoksi empiirisen lähestymistavan tärkeyttä korostetaan voimakkaasti.

Yhteenvedossa otetaan kantaa myös siihen, millaisena variaatio näyttäytyy vuorovaikutuslingvistiikan näkökulmasta, ja pohditaan, onko vuorovaikutuksesta löydettävissä jonkinlaisia universaaleja, kaikkia kieliä ja kulttuureita yhdistäviä ilmiöitä tai periaatteita. Koska vuorovaikutuslingvistinen tutkimus monista maailman kielistä on toistaiseksi varsin puutteellista, ei universaaleja ole juurikaan pystytty osoittamaan - ainakaan vielä. Couper-Kuhlen ja Selting kuitenkin mainitsevat (s. 552), että viimeaikainen tutkimus on ehdottanut yhdeksi universaaliksi interjektiota, jonka teoksessa esitetään olevan muotoa huh?. Kyseisen interjektion morfofonologinen muoto vaihtelee hieman eri kielissä, mutta kyseessä on avoin yksitavuinen ilmaus, joka koostuu laveasta väljästä etuvokaalista, jonka alussa on glottaali [h] tai [?] ja joka on tuotettu kysyvällä intonaatiolla. Tällaista interjektiota on osoitettu käytettävän merkittävässä määrässä maailman kieliä avoimena toisen vuoroon kohdistuvana korjausaloitteena (ks. Dingemanse, Torreira \& Enfield 2013). Suomenkielisille puhujillekin interjektio lienee tuttu muodossa hä $(h)$ ? (ks. Haakana, Kurhila, Lilja \& Savijärvi 2016). Toisaalta universaalius on myös kyseenalaistettu (ks. esim. Garly 2016 tanskan kielen osalta).

\section{Lopuksi}

Vuorovaikutuslingvistiikkaa esittelevä oppikirja tulee tarpeeseen. Interactional linguistics: Studying language in social interaction kokoaa yhteen eri aiheista vuosikymmenten aikana tehtyä tutkimusta, esittelee sitä havainnollistavasti ja pedagogisesti sekä tekee aiemman tutkimuksen perusteella mielenkiintoisia johtopäätöksiä kielellisen vuorovaikutuksen luonteesta. Koska kyseessä on akateeminen oppikirja, ensisijaisia kohderyhmiä lienevät opinnoissaan pidemmälle ehtineet opiskelijat sekä kielellisen vuorovaikutuksen tutkimista kursseillaan opettavat tutkijat, jotka voivat käyttää kirjaa opetuksensa tukena. Täysin keskustelunanalyysia tuntemattomalle lukijalle teos ei kuitenkaan välttämättä ole kovin helposti 
lähestyttävä; vaikka keskustelunanalyysin keskeisiä käsitteitä avataan, varsinkin osion I lukujen ymmärtämisessä jonkinlainen lähestymistavan esiymmärrys on tarpeen.

Teoksen kirjoittajat ovat tehneet suuren työn, ja kyseessä on tärkeä teos vuorovaikutuslingvistiikan tunnetuksi tekemisen ja aseman vakiinnuttamisen kannalta. Teos toimii sekä kannesta kanteen luettavana oppikirjana että käsikirjana, josta on helppo poimia oman kiinnostuksensa kannalta relevantteja huomioita ja lähteitä. Tämän lisäksi se tarjoaa erinomaisen katsauksen siihen, mikä on vuorovaikutuslingvistisen tutkimuksen tila tällä hetkellä: mitä on jo tehty, mikä puolestaan odottaa vielä jatkotutkimusta. Lukija - niin pidemmälle ehtinyt vuorovaikutuslingvisti kuin vasta opinnäytetyötään valmisteleva opiskelija - voikin käyttää teosta inspiraation lähteenä ja poimia siitä aiheita, joista on toistaiseksi vain vähän tai ei lainkaan tutkimusta.

Karita Suomalainen etunimi.m.sukunimi@utu.fi

Kirjoittaja on suomen kielen väitöskirjatutkija Turun yliopistossa.

\section{Lähteet}

Couper-Kuhlen, Elizabeth - SeltING, Margret (toim.) 1996: Prosody in conversation. Interactional studies. Cambridge: Cambridge University Press. https://doi.org/10.1017/ CBO9780511597862.

Couper-Kuhlen, Elizabeth - Selting, MARGRET 2001: Introducing interactional linguistics. - Margret Selting \& Elizabeth Couper-Kuhlen (toim.), Studies in interactional linguistics s. 1-22. Amsterdam: John Benjamins. https:// doi.org/10.1075/sidag.10.02cou.

Dingemanse, Mark - Torreira, Francisco - ENFIELD, Nick 2013: Is huh? a universal word? Conversational infrastructure and the convergent evolution of linguistic items. - PLoS ONE 8(11). https://doi.org/10.1371/journal. pone.0094620.soo2.

Garly, Katrine 2016: Hvar - det danske huh. En kollektionsanalyse af åbenklasse andeninitieret selvreparatur på dansk. - Skrifter om Samtalegrammatik 3(3). http://samtalegrammatik.dk/fileadmin/ samtalegrammatik/sos/3/Garly_2016_ Hvar_det_danske_huh.pdf (29.4.2019).

HaAkana, Markku - Kurhila, Salla - Lilja, Niina - Savijärvi, Marjo 2016: Kuka, mitä, häh? Korjausaloitteet suomalaisessa arkikeskustelussa. - Virittäjä 120 s. 255-292.

Hakulinen, Auli - Selting, Margret (toim.) 2005: Syntax and lexis in conversation. Studies on the use of linguistic resources in talk-in-interaction. Amsterdam: Benjamins.

Helasvuo, Marja-Lisa 2014: Jotta suomalaiset voisivat puhua enemmän. Puhetilanteen osallistuja tekstiviestikeskustelussa. - Marja-Liisa Helasvuo, Marjut Johansson \& Sanna-Kaisa Tanskanen (toim.), Kieli verkossa. Näkökulmia digitaaliseen vuorovaikutukseen s. 29-49. Helsinki: Suomalaisen Kirjallisuuden Seura.

Helasvuo, Marja-LiIsa - KärKKäInen, Elise - Endo, Toмоко (toim.) 2018: Units in responsive turns. - Journal of Pragmatics 123 s. 117-238.

ISK = HAKULINEN, AULI - VILKUNA, Maria - Korhonen, Rittta Koivisto, Vesa - Heinonen, Tarja Riitta - Alho, IrJa 2004: Iso suomen kielioppi. Helsinki: Suomalaisen Kirjallisuuden Seura.

LAury, Ritva - Etelämäki, MarJa Couper-Kuhlen, Elizabeth (toim.) 2017: Linking clauses and actions in social interaction. Studia Fennica Linguistica 2o. Helsinki: Suomalaisen Kirjallisuuden Seura. 
Lindström, JAN - MASchler, YAel Pekarek Doehler, Simona (toim.) 2016: Grammar and negative epistemics in talk-in-interaction. Cross-linguistic studies. - Journal of Pragmatics 106 S.72-2O2.

Linell, Per 2005: The written language bias in linguistics. Its nature, origins and transformations. London: Routledge.

Ochs, Elinor - Schegloff, Emanuel Thompson, SANDra (toim.) 1996: Interaction and grammar. Studies in interactional sociolinguistics 13. Cambridge: Cambridge University Press. https://doi. org/10.1017/CBO9780511620874.

Schegloff, Emanuel - Ochs, Elinor - Thompson, SANDra 1996: Intro- duction. - Elinor Ochs, Emanuel A. Schegloff \& Sandra Thompson (toim.), Interaction and grammar. Studies in interactional sociolinguistics $13 \mathrm{~s}$. 1-51. Cambridge: Cambridge University Press. https://doi.org/10.1017/ CBO9780511620874.001.

Selting, Margret - Couper-Kuhlen, Elizabeth (toim.) 2001: Studies in interactional linguistics. Amsterdam: John Benjamins. https://doi.org/10.1075/ sidag.10.

TANAKA, Нівоко 1999: Turn-taking in Japanese conversation. A study in grammar and interaction. Amsterdam: John Benjamins. https://doi.org/10.1075/pbns.56.

\section{Tuntevasti Suomessa puhutuista kielistä ja kielitietoisuudesta}

\begin{abstract}
Mari Honko \& Sanna Mustonen (toim.): Tunne kieli. Matka maailman kieliin ja kielitietoisuuteen. Helsinki: Finn Lectura 2018. 474 s. ISBN 978-951-792-923-3.
\end{abstract}

"Kielitietoisessa koulussa kaikki opiskeltavat kielet ja oppilaiden äidinkielet näkyvät luontevasti. Kielitietoiset työtavat edellyttävät opettajien yhteistyötä. Koulussa tulee luoda yhteistyölle rakenteet ja toimintaedellytykset." Näin todetaan Opetushallituksen Kielitietoinen opetus kielitietoinen koulu -julkaisussa (KOKK 2017: 7). Monikielisyyttä ja äidinkielistä identiteettiä riittävästi tukemalla voidaan helpottaa uuden kielen oppimista ja opinnoissa menestymistä. Mari Hongon ja Sanna Mustosen toimittama teos Tunne kieli: Matka maailman kieliin ja kielitietoi- suuteen tekee näkyväksi nyky-Suomessa puhuttavien kielten kirjoa. Teos pyrkii lisäämään kielitietoisuutta ja tarjoamaan monikielisyydestä yleistajuista tietoa opettajille ja muille monikielisissä yhteisöissä työskenteleville.

Hongon ja Mustosen teoksella on varsin kunnianhimoiset tavoitteet. Teoksessa tutustutaan diversiteetin, kielitietoisuuden ja kielitiedon käsitteisiin, monikielisyyden muotoihin sekä vertaillaan Suomessa puhuttavia vähemmistökieliä suomen kieleen. Käsiteltävinä ovat arabian, bengalin, kiinan, kurdin, persian, romanian, somalin, tagalogin, thain, turkin, venäjän, vietnamin ja viron kielet. Johdannossa hahmotellaan kohdeyleisöksi monikielisissä ympäristöissä työskentelevät opettajat, varhaiskasvattajat ja kieli- 